\title{
Effects of MicroRNA-499 On the
}

Inflammatory Damage of Endothelia During Coronary Artery Disease Via th Targeting of PDCD4 Through the $\mathrm{N}$ TNF- $\alpha$ Signaling Pathway

\author{
Yu-Hong Zhang Keng He Gang Shi
}

Department of Cardiovascular Medicine, Jiangxi Pingxiang People's

M, Pin.yxiang P.R. China

Key Words Microrna-499 $\cdot$ Programmed cell death
pathway $\bullet$ Endothelial cells $\cdot$ Inflamm on disease $\cdot N F-k B / T N F-\alpha$ signaling

\section{Abstract}

Background/Aims: This stud

ed to analyze the impact of microRNA-499 (miR-499) on the inflammatory damage targeting of PDCD4 thro CAD patients (CAD grou Endothelial cells yere co 1 the Ni/TN- $\alpha$ signaling pathway. Methods: A total of 216 cells during coronary artery disease (CAD) via the nd 9 healthy people (normal group) were enrolled in our study. nd assigned into normal, OX-LDL, negative control (NC), miR-499 inhibit 499 mimic, PDCD4 siRNA, and miR-499 inhibitor + PDCD4 siRNA groups. The $q$ vestern blotting were performed to detect the mRNA and protein expression vels Dr, 4 and miR-499. The MTT assay was performed to determine cell viability A wa cormed to determine the expression levels of inflammatory factors, and flow metry assay to evaluate cell apoptosis. Results: Increased miR-499 expression ecrea. DCD4 expression in the plasma were observed in the CAD group compared narmal group, demonstrating a negative correlation between miR-499 and PDCD4. the normal and miR-499 inhibitor groups, the survival rate of cells and PDCD4 ression were decreased; and the expressions of miR-499, IL-6, IL-8, IL-1 $\beta$, TNF- $\alpha$, NF-kB, C 1 - ICAM-1 and MCP-1 and the apoptosis rate were all elevated in the OX-LDL, NC, 499 mimic, PDCD4 siRNA and miR-499 inhibitor + PDCD4 siRNA groups. Compared to ne OX-LDL, NC and miR-499 inhibitor + PDCD4 siRNA groups, PDCD4 expression and the

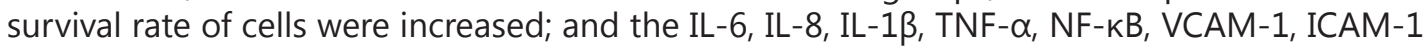
and MCP-1 expression levels and the apoptosis rate were all reduced in the miR-499 inhibitor group. In the PDCD4 siRNA group, PDCD4 expression and the survival rate of cells were lower, and the expression levels of IL- 6 , IL- 8, IL- $1 \beta$, TNF- $\alpha$, NF- $\mathrm{kB}$, VCAM-1, ICAM- 1 and MCP- 1 and the apoptosis rate were all higher compared with the miR-499 mimic group. In the miR-499 


\section{Cellular Physiology \begin{tabular}{l|l|l} 
and Biochemist 10.1159/000484588 & $\begin{array}{l}\text { C } 2017 \text { The Author(s). Published by S. Karger AG, Basel } \\
\text { www.karger.com/cpb }\end{array}$
\end{tabular} \\ Zhang et al.: Effects of Mir-499 On CAD by Targeting PDCD4}

inhibitor + PDCD4 siRNA group, PDCD4 expression and the survival rate of cells were higher, and the expression levels of IL- 6 , IL- 8 , IL- $1 \beta$, TNF- $\alpha$, NF-KB, VCAM-1, ICAM- 1 , and MCP- 1 and the apoptosis rate were all lower than those in the PDCD4 siRNA group. Conclusion: Downregulated miR-499 expression increased PDCD4 expression and protected endothelial cells from inflammatory damage during CAD by inhibiting the NF-KB/TNF- $\alpha$ signaling pathway.

\section{Introduction}

Coronary artery disease (CAD), as the most common etiology of hea tttack death in the world, is a multifactorial disease caused by the combined impact of es The main etiology of CAD is characterized by defective endothelial funct the underlying mechanism has not been fully elucidated despite the high inci of CA Although there are many recent advancements in treatment, the mortalin by still increasing. Genetic features are crucial and constant risk factors $f_{0} \quad A D p$. nesis. Recently, one study investigated the relationship between CAD ana tic predisposition and showed that $40 \%$ to $60 \%$ of the risk for CAD is related onetic p. osition [3].

MicroRNAs (miRNAs) are a group of single-strano onous ncoding RNAs of approximately 22 nucleotides that regulate gene ex sio ither translational repression or mRNA degradation [4]. MicroRNA-499 (mi is arecently discovered member of the miRNAs encoded by myosin [5 nder normo vsiological circumstances, there is a low expression level of miR-499 re ing the ex ssion of the beta myosin heavy chain, leading to the enhancement of my oxygen metabolism and tolerance [6]. It has recently been demonstrated that (-4) pression is significantly changed in certain heart diseases such as valvular he tise? schemic heart disease and heart failure [7]. MiR-499 has been proven to ach as FOXO4 and programmed cell death 4 (PDCD4) [8].

PDCD4 is a highly conserved RNA thein that inhibits the translation of specific mRNAs [9]. As a significant ty multiple genes, and regulates is sighun ansduction pathways [10]. It may play a pivotal role in arresting cell cycle $r$ git $\quad$ inhibit cell proliferation and tumor metastasis [11]. One study showed that an moa various signal transduction pathways; specifically, the study results dem rated that up-regulated miR-182 and down-regulated PDCD4 were observed in ovaria cell lines, while blocking miR-182 in ovarian cancer cell lines resulted $j$ osim alteration in endogenous PDCD4 protein expression, which was beneficia or cancer treatment [10]. Nuclear factor kappa B (NF- $\mathrm{kB})$, one of the most cical na uthways, regulates genes correlated with proliferation, apoptosis, immune oons ammation and tumorigenesis [12]. It can react to harmful stimuli i' $\urcorner$ medic. modulating molecules that involved in the early immunological reaction as well amm in all stages [13]. A study revealed that NF- $\mathrm{BB}$ caused apoptosis resistance er an played a role in carcinogenesis [14]. Inflammation is of great significance cular disease like atherosclerosis and especially, during the early phase of erogenesis, inflammation occurs in vascular endothelium and the inflamed endothelial 1) xines, and adhesion molecules [15]. Tumor necrosis factor-alpha (TNF- $\alpha$ ) is regarded a pleiotropic cytokine that is involved in the pathophysiology of inflammatory diseases [16]. CAD, as a chronic inflammatory disease that results from atherosclerosis, is mediated to some extent by proinflammatory cytokines, especially TNF- $\alpha$, which is often expressed in atherosclerotic plaques [17]. Because the effects of miRNAs have not been systematically explained, we intended to determine the potentially regulatory mechanism of miRNA on certain target genes. Here, we investigated the effects of miR-499 on inflammatory damage in endothelial cells during CAD via the inhibition of the PDCD4 gene through the NF- $\mathrm{KB}$ / TNF- $\alpha$ signaling pathway.

\section{KARGER}




\section{Cellular Physiology Cell Physiol Biochem 2017;44:110-124

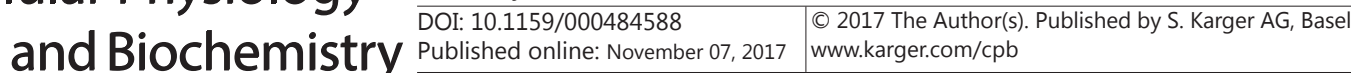 \\ Zhang et al.: Effects of Mir-499 On CAD by Targeting PDCD4}

\section{Materials and Methods}

\section{Ethics statement}

All patients were informed and provided signed informed consent. The experiment was approved by the Experiment Ethics Committee of Jiangxi Pingxiang People's Hospital.

\section{Study subjects}

A total of 216 CAD patients were recruited in the Department of Cardiovascular Diseases of Jia Pingxiang People's Hospital from January to December of 2015; they formed the CAD group with 132 and 84 females aged 40-88 years old with a mean age of 59.82 years old. The inclusion criter the CAD diagnostic criteria [18]: patients with chest discomfort and/or ischemic ST-T changes a by an electrocardiograph (ECG), and coronary angiography (CAG) showing the four ma ries of the left main (LM), left anterior descending (LAD), left circumflex (LCX) and right co artery with at least one artery containing pathological changes of stenosis $\geq 50 \%$. The ro rit ria 19] were as follows: patients with other severe systemic diseases such as cancer, lungd ase, cl , severe infection, acute infectious disease, severe liver and kidney dysfunction, hemorn lisease, autoimmune disease and tuberculosis or those who recently underwent major ries. Nin - althy people who underwent physical examination in the medical examination cen cliang Agxiang People's Hospital were recruited for the normal group, including 54 males an fen were 37-81 years old with a mean age of $56.20 \pm 9.82$ years old. No significant difference wâ two groups $(P>0.05)$.

\section{Collection and preservation of plasma}

In the morning, $3 \mathrm{~mL}$ of peripheral venous blood exth from the patients in the CAD and normal groups. All blood samples were collected using ethylen mine acetic acid (EDTA) anticoagulant tubes, and they were centrifuged $(3,000 \mathrm{~g})$ at $4^{\circ} \mathrm{C}$ for ${ }^{1}$ in th separation. The supernatant (plasma) was placed in RNase-free eppendorf (EP) tubes

Primary culture of human ur

Healthy maternal-fetal umbi

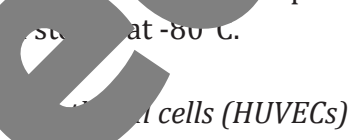

in ay or gender between the stump of the umbilical cord y vie biogical safety cabinet with $75 \%$ ethyl alcohol. After the part with the clamp mark w at off, th avenous residual blood was rinsed with phosphate-buffered solution (PBS), and the umb l cord was sequentially perfused with preheated $0.25 \%$ trypsin and $0.02 \%$ EDTA digestion liquid to fill al cord. Then, the umbilical cord was put into a water bath at $37^{\circ} \mathrm{C}$ for digestion for digcurve enzyme was collected, and the vein was rinsed with PBS. The two solutions were ef $\quad d$ and centrifuged for $10 \mathrm{~min}$. The supernatant was removed. Cells were resuspender vith oulbecco's modified Eagle's Medium (DMEM) containing 10\% fetal bovine serum (F CAS: 1 J4, Gibco, New York, USA), $100 \mu / \mathrm{mL}$ penicillin, $100 \mu / \mathrm{mL}$ streptomycin and $1\urcorner 0 \mathrm{mg} / \mathrm{L} \quad$ thelial cell growth supplement (ECGs), inoculated in a flask and placed in the incubator at ith 5, for $24 \mathrm{~h}$. After the cells adhered to the wall of the flask, the medium was changed, and 's as wu, as red blood cells were removed. Thereafter, the medium was changed every two days. performed when the cells grew to $80 \%-90 \%$ confluence. The experiments were performed the mird-generation cells.

Acquired HUVECs were inoculated to a 6-well plate containing coverslips. After the HUVECs reached $60 \%$ confluence, the coverslip was removed, rinsed three times with sterile PBS, fixed with $3 \%$ paraformaldehyde at room temperature for $15 \mathrm{~min}$ and washed with sterile PBS three times. After that, the coverslip was incubated in $3 \% \mathrm{H}_{2} \mathrm{O}_{2}$ for $8 \mathrm{~min}$, washed with PBS three times, and incubated with goat serum for 15 min. Rabbit anti-human VIII factor-related antigen (No. SP0731, Ascend Biotechnology Co., Ltd, Guangzhou, China) was incubated with the coverslips overnight at $4^{\circ} \mathrm{C}$. In the NC group, the primary antibody was replaced by PBS for incubation. On the second day, the sample was washed three times with PBS and incubated with fluorescein isothiocyanate (FITC)-labeled goat anti-rabbit IgG (No. ZDR-5118, ZSGB$\mathrm{BIO}$, Beijing, China) at $37^{\circ} \mathrm{C}$ for $30 \mathrm{~min}$. After washing with PBS, the coverslip was put under a microscope for 


\section{Cellular Physiology

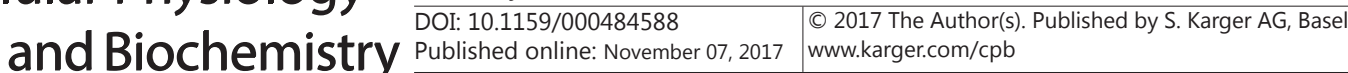 \\ Zhang et al.: Effects of Mir-499 On CAD by Targeting PDCD4}

cell morphology observation and imaging. VIII factor-related antigen positive expression in the endothelial cells was detected by immunofluorescence.

\section{Establishment of an inflammatory injury model using endothelial cells}

The HUVEC inflammatory injury model was established through the induction of oxidized low-dens; lipoprotein (OX-LDL) (No. UBC_oxldl, Peking Union-Biology Co. Ltd, Beijing, China) [20]. HUVECs in th logarithmic phase were digested with $0.25 \%$ trypsin. A cell suspension was made, and the cell concentration was adjusted to $1 \times 10^{6}$ cells $/ \mathrm{mL}$; then, $2 \mathrm{~mL}$ of DMEM medium containing $100 \mu \mathrm{g} / \mathrm{mL}$ OX-LDL was ad Cells were put in the incubator with $5 \% \mathrm{CO}_{2}$ at $37^{\circ} \mathrm{C}$ for $24 \mathrm{~h}$. When the cells reached $80 \%-90 \%$ conflu subculture was performed for subsequent experiments.

\section{Dual-luciferase reporter assay}

The miR target gene prediction tool Targetscan (http://www.targetscan.org/ to predict the binding site of miR-499 in the PDCD43'UTR. The PDCD4 3'UTR prop containing the miR-499 binding site was synthesized and inserted at the 5' end Bgll vector to construct the PDCD4 3'UTR wild-type (WT) plasmid (named as PDC plasmid, the miR-499 binding site was mutated, and the resultant sea was usec. struct the PDCD4 3'UTR mutant (MUT) plasmid (named as PDCD4 3'UTR-MUT). Ace instru of the plasmid extraction kit (12145, QIAGEN, Valencia, CA), NC + PDCD4-WT, NC + D4- -499 mimic + PDCD4WT, miR-499 mimic + PDCD4-MUT, miR-499 inhibitor + PDCD4-WT a 49, uhibitor + PDCD4-MUT were transfected into HUVECs. The reporter gene vec used in the en ment was pcDNA3.l-luc, which encodes firefly luciferase. To measure the transfection $t \quad c y, p R L-T K$ co-transfected and used as the internal control. The pRL-TK plasmid encoded renilla lum The preheated fluorescent agent was used to set the parameters. After adjusting to zero, $40 \mu \mathrm{L}$ of $\quad \mathrm{NII}$ a $\quad \mathrm{uL}$ of STOP\&Glo reagent were added to the sample tube, which was put in the fluorimeter for 'ing. 'uorescence value was recorded.

\section{Cell grouping and transfection}

MiR-499, PDCD4 inhibitor and the an: by Shanghai GenePharma. Based groups: the normal group (norma. induced by OX-LDL without siec siRNA); the miR-499 inhibit mimic group (OX-LDL groul with transfection of PDCD4 and the miR-499 inhibitor + PDCD4 siRNA group (OX-LDL group roup $\mathrm{O}$

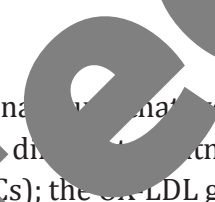
Cs); the DL group (endothelial cell inflammatory injury model NC group (OX-LDL group with transfection of irrelevant group with transfection of miR-499 inhibitor); the miR-499 with transfection 9 inmontor and PDCD4 inhibitor). Using liposomal Lipofectamine 3000 (CAS: L3000-015, Invi ge, USA), transient transfection was performed. HUVECs were subcultured
one day bef the $90 \sim 95 \%$ L of s r medium was used to dilute $1.0 \mu \mathrm{g}$ of DNA, and then, another $50 \mu \mathrm{L}$ of serumf ' ' me med s used to dilute $1 \mu \mathrm{L}$ of Lipofectamine 3000 transfection reagent. After evenly mixing, the 1 was with the diluted DNA and put at room temperature for $20 \mathrm{~min}$. After the medium was each 11 was supplemented with the compound, and the culture plate was shaken to mix the y. Then, the cells were cultured in the incubator with $5 \% \mathrm{CO}_{2}$ at $37^{\circ} \mathrm{C}$. Four hours later, the

lium was replaced. After a 48-hour transfection, the subsequent experiment was carried out.

Quantitative real-time polymerase chain reaction ( $q R T-P C R$ )

According to the instruction of the kit (CAS: 74104, QIAGEN, Valencia, CA), total RNA of the plasma and cells was extracted. The OD260/280 value of the extracted RNA was detected with an ultraviolet spectrophotometer, and the RNA concentration was calculated. Then, the samples were stored properly at $-80^{\circ} \mathrm{C}$. Reverse transcription of cDNA was performed following the instructions of the kit (CAS: 205311, QIAGEN, Valencia, CA). Gene sequences published by the GenBank database and the Primer5.0 primer design software were used to design specific primers. The designed primers are displayed in Table 1 . The designed primers were synthesized by Shanghai Sangon Biotech (Shanghai, China). The PCR reaction system was generated in a $20-\mu \mathrm{L}$ volume: $10 \mu \mathrm{L}$ of SYBR PremixExTaq, $0.8 \mu \mathrm{L}$ of forward primer, $0.8 \mu \mathrm{L}$ of reverse primer, $0.4 \mu \mathrm{L}$ of ROX Reference Dye II, $2 \mu \mathrm{L}$ of DNA template and $6.0 \mu \mathrm{L}$ of $\mathrm{dH}_{2} \mathrm{O}$. The reaction conditions 


\section{Cellular Physiology \begin{tabular}{l|l|l} 
and Biochemistry 10.1159/000484588 & $\begin{array}{l}\text { C } 2017 \text { The Author(s). Published by S. Karger AG, Basel } \\
\text { www.karger.com/cpb }\end{array}$
\end{tabular} \\ Zhang et al.: Effects of Mir-499 On CAD by Targeting PDCD4}

Table 1. The primer sequences for qRT-PCR, Note: miR499, microRNA-499; PDCD4, programmed cell death 4; ICAM-1, intercellular cell adhesion molecule-1; MCP-1, monocyte chemotactic protein-1; VCAM-1, vascular cell adhesion molecule-1; NF- $\mathrm{kB}$, nuclear factor-kappa B; TNF- $\alpha$, tumor necrosis factor-alpha; GAPDH, glyceraldehyde-3-phosphate dehydrogenase, F, forward; R, reverse, qRT-PCR, quantitative real-time polymerase chain reaction

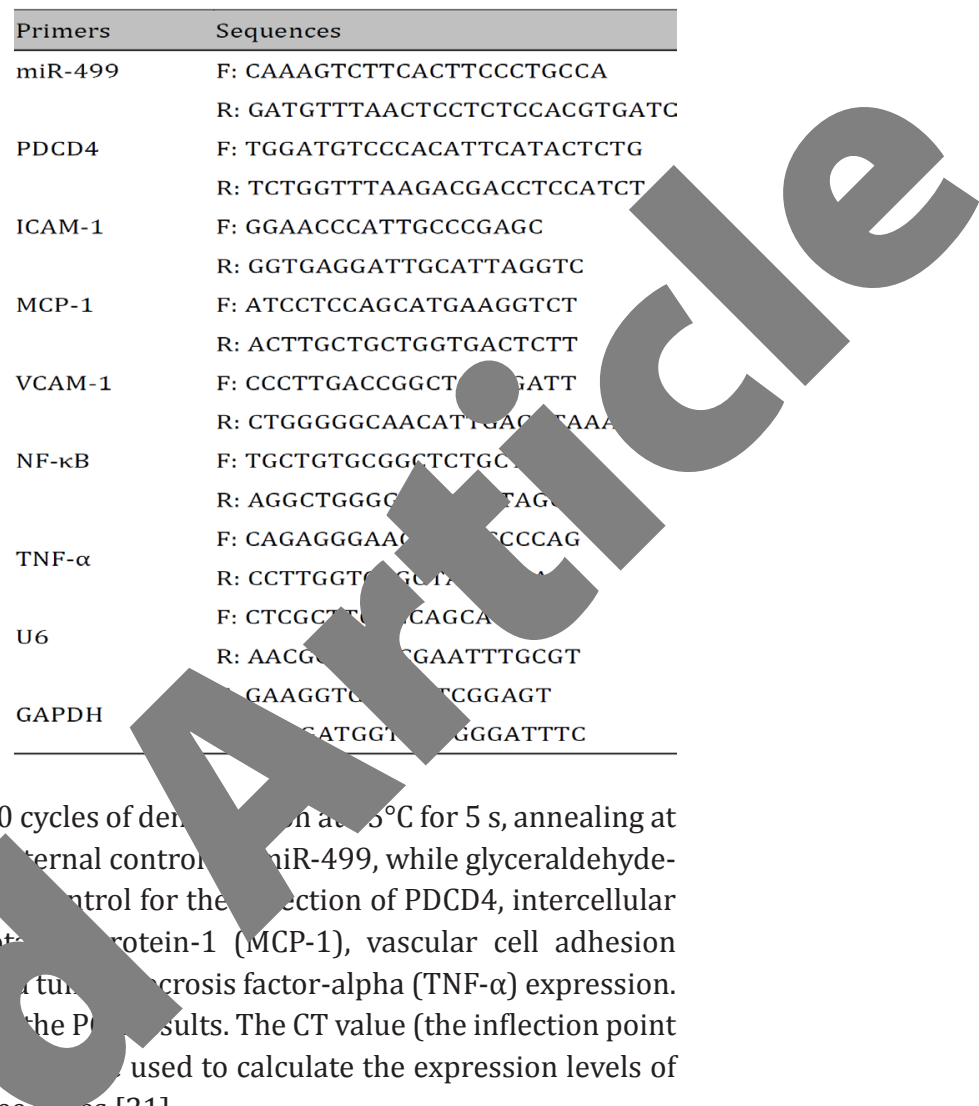

were predenaturation at $95^{\circ} \mathrm{C}$ for $30 \mathrm{~s}$ and underwent 40 cycles of der $60^{\circ} \mathrm{C}$ for $30 \mathrm{~s}$ and extension at $72^{\circ} \mathrm{C}$ for $30 \mathrm{s.} \mathrm{U} 6$ was thernal contro n au $\sigma^{\circ} \mathrm{C}$ for $5 \mathrm{~s}$, annealing at cell adhesion molecule-1 (ICAM-1), monocyte chemot rotein-1 (MCP-1), vascular cell adhesion molecule-1 (VCAM-1), nuclear factor-kappa B (NF- $\mathrm{B}$ ) tur. crosis factor-alpha (TNF- $\alpha$ ) expression. The solubility curve was used to evaluate the reliabilit he Pults. The CT value (the inflection point of the power amplification curve) and the form of $\angle$ used to calculate the expression levels of the target genes, and each experiment was r ay ree unies [21].

\section{Western blotting}

Proteins were extracted from

neach gruap, and the concentration was determined in accordance with the instructions of the $\mathrm{BC}$ added and separated by $10 \%$ from $80 \mathrm{~V}$ to $120 \mathrm{~V}$. Wet tran After transferring the nrote samples were seal antibodies agair CRUZ, Califo SANTA $C^{*}$ Califo SA) and GAPDH (CAS: sc-47724, SANTA CRUZ, California, USA) were added. Beyotime, Beijing, China). In each well, $30 \mu \mathrm{g}$ of protein was
el electrophoresis. The electrophoresis voltage was changed was ca ried out, and the transmembrane voltage was $100 \mathrm{mv}$ for 45-70 min. yvinylidene fluoride (PVDF) membrane at room temperature, the o burne serum albumin (BSA) for $1 \mathrm{~h}$. Then, primary anti-mouse monoclonal S: sc-8439, SANTA CRUZ, California, USA), VCAM-1 (CAS:sc-13160, SANTA A lll of the antibodies were diluted to 1:1000 and incubated overnight at $4^{\circ} \mathrm{C}$. The membrane was with yffered saline Tween (TBST) three times for 5 min each. A goat anti-mouse IgG secondary (1:10, was incubated with the membrane for $1 \mathrm{~h}$ at room temperature. Then, the membrane was nee times for 5 min each. The Gel Doc EZ imager (Bio-Rad, California, USA) was used to. GAPD alize nre protein bands. GAPDH was used as the internal reference. The Image J software was used to nal a the gray values of the target bands. Each experiment was repeated three times.

Methyl-thiazolyl-tetrazolium (MTT) assay

The diluted cell suspension was inoculated onto a 96-well plate with $5 \times 10^{4}$ cells per well. When cells adhered to the wall and the cell confluence reached $80 \%$, the cells were treated as indicated by the experimental grouping. In each group, 6 parallel wells were used. The medium was discarded after $48 \mathrm{~h}$ in culture. Serum-free medium was supplemented to every well, and then, the cells were washed 3 times. Then, $20 \mu \mathrm{L}$ of MTT solution (CAS: M2128-1G, Sigma, CA, USA) was added, and the plates were put in the incubator at $37^{\circ} \mathrm{C}$ for $4 \mathrm{~h}$; then, the MTT solution was discarded. Then, $150 \mu \mathrm{L}$ of dimethyl sulfoxide (DMSO) was added into each well. After shaking for $10 \mathrm{~min}$, the optical density (OD) value of each well was recorded at the wavelength of $490 \mathrm{~nm}$ in the microplate reader. The experiment was carried out in triplicate, and the 


\section{Cellular Physiology \begin{tabular}{ll|l} 
and Biochemistry Published online: November 07, 2017 & $\begin{array}{l}\text { (c) } 2017 \text { The Author(s). Published by S. Karger AG, Basel } \\
\text { www.karger.com/cpb }\end{array}$ \\
\hline
\end{tabular} \\ Zhang et al.: Effects of Mir-499 On CAD by Targeting PDCD4}

average OD value was calculated. The cell survival rate $=\left(\right.$ experiment group $_{\text {oD value }}-$ control group $\left._{\text {oD value }}\right) /$ control group $_{\text {oD value }}$. Each experiment was repeated three times.

Enzyme-linked immunosorbent assay (ELISA)

ELISA kits (No. EK0997, Boster, Wuhan, China) were utilized to determine the levels of tumor necro factor alpha (TNF- $\alpha$ ), interleukin 1 (IL-1), interleukin 6 (IL-6) and interleukin 8 (IL-8). First, the standar solutions, the biotin-labeled antibody and the avidin-biotin-peroxidase complex (ABC) were prepared. Diluted ABC and tetramethylbenzidine (TMB) developing solutions were preheated. The number of EI plates was determined. Cell supernatants were taken from each group, and the samples to be-detected acquired following centrifugation; then, $100 \mu \mathrm{L}$ of the standard samples and the diluted sam to the ELISA plate. After reacting with the wells of the plate, the liquid in the plate was disca well, $100 \mu \mathrm{L}$ of biotin antibody was added to react for $60 \mathrm{~min}$. The sample was washed $t$ and $100 \mu \mathrm{L}$ of $\mathrm{ABC}$ liquid was added to react for $30 \mathrm{~min}$. Then, the samples were washec and $90 \mu \mathrm{L}$ of the TMB developing liquid was added to react without light for $30 \mathrm{~min}$ stopping buffer was added, and the OD value was measured at a wavelength of 45 reader. Based on the OD value, the corresponding concentration on the standara concentration of the sample was detected by multiplying the dilutior three times.

Flow cytometry assay

Cell apoptosis was detected using the Annexin $y$ (product N 002, Bogoo, Shanghai, China). The medium in each group was collected and placed h entrifuge th the sample was washed with PBS, followed by the addition of $0.25 \%$ trypsin for cell $d$ After cell percussion, the digestion liquid was collected and added into the originally collected aun samples were centrifuged at $1000 \mathrm{~g}$ for 5 min at $4^{\circ} \mathrm{C}$, and the cell sediment was collected. Th nple e adjusted to achieve a $5 \sim 10$ million cell suspension and were centrifuged at $1000-5 \quad$ supernatant was removed, and $195 \mu \mathrm{L}$ of Annexin V-FITC binding buffer was added; 11 , ells vere resuspended. After an addition of $5 \mu \mathrm{L}$ of Annexin V-FITC, the solution was mixed e $10 \mathrm{~min}$ at room temperature without light and centrifuged at $1000 \mathrm{~g}$ for $5 \mathrm{~m} \quad \mathrm{su} \quad$ as removed, and $190 \mu \mathrm{L}$ of Annexin V-FITC binding buffer was added. Then, $10 \mu \mathrm{L}$ of dium loun (PI) single staining solution was added. After evenly mixing, the sample was restore nan for flow cytometry assay (No. FACSCanto II, BD, Jersey, USA). Early apoptosis set as $\mathrm{s}$ ver right quadrant, late apoptosis was set as the upper right quadrant, and the live cells in th lower left quadrant. The apoptosis rate $=$ the early apoptosis rate + the late apoptosis rate Fach was repeated three times.

Statistical $y$ ?

The SP 21.0 ist software (SPSS, Inc, Chicago, IL, USA) was used. The measurement data are presente standard deviation. Comparisons of measurement data with normal distribution b tween vups were made using $t$ tests, while comparisons among multiple groups were made using $y$ an $P<0.0$ was considered statistically significant.

\section{Results}

Relative expression of plasma miR-499 and PDCD4 in the normal and CAD groups

The qRT-PCR was used to detect the mRNA expressions of miR-499 and PDCD4 in the normal and CAD groups. The results showed that compared with the normal group, the expression of miR-499 in the CAD group was significantly increased while that of PDCD4 was significantly decreased $(P<0.05)$ (Fig. 1A). The results of the Pearson correlation analysis showed that mRNA expressions of miRNA-499 and PDCD4 were negatively correlated $(\mathrm{r}=$ $-0.512, P<0.05$ ) (Fig. 1B). 
Morphological observation and identification of HUVECS

The morphology of HUVECs was observed under an inverted microscope. It was noted that HUVECs were round, polygonal or spindle shaped. The cells showed monolayer growth without overlapping. A few cells extended and presented in arrangements similar to cobblestones or paving stones after confluence (Fig. 2A and B). VIII factor-related antigen was specific to endothelial cells. The rabbit anti-human VIII factor-related antigen primary antibodies were incubated with a secondary antibody. Green fluorescence was emitted in HUVECs. In the control group, the primary antibody was replaced by PBS, and thus, green fluorescence was not observed (Fig. 2C and D). The results suggested that the cells isolated from human umbilical vein were endothelial cells.

PDCD4 was verified as target gene of miR-49

The online miRN/ gene prediction tool Ta (http://www.tarmesca vert_71/) pred genes of mir $9^{\circ}$ sults showed 3 cial miR-

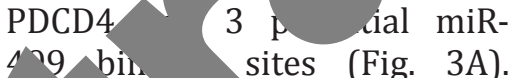
rase ter gene activity esults showed that in co-transfected with d-type PDCD4 3'UTR-WT -or ared with the NC group, elative activity of luciferase the miR-499 mimic group
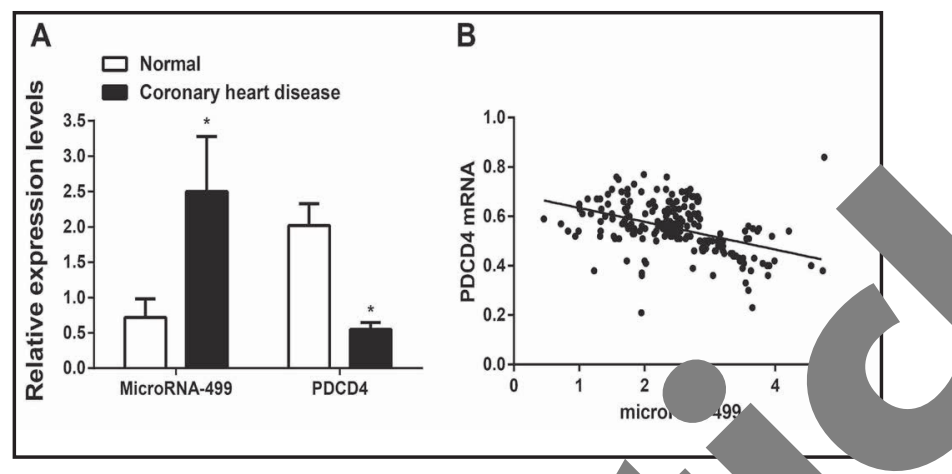

Fig. 1. Relative mRNA expressions of plasma $9 \mathrm{a}$ in the normal and CAD groups as detected by $\mathrm{CR}$. A: A expressions of miR-499 and PDCD4 in plas as PCR; and B: correlation of the mRNA exp ns of nt NA-499 and PDCD4 as analyzed by Pearson con $\quad n$ analysis; ${ }^{*}, \mathrm{P}<0.05$ compared with the normal aRT-PCh titative real-time polymerase chain react mich iNA-499; PDCD4, programmed cell death 4 ; a AP $\quad$ artery disease.

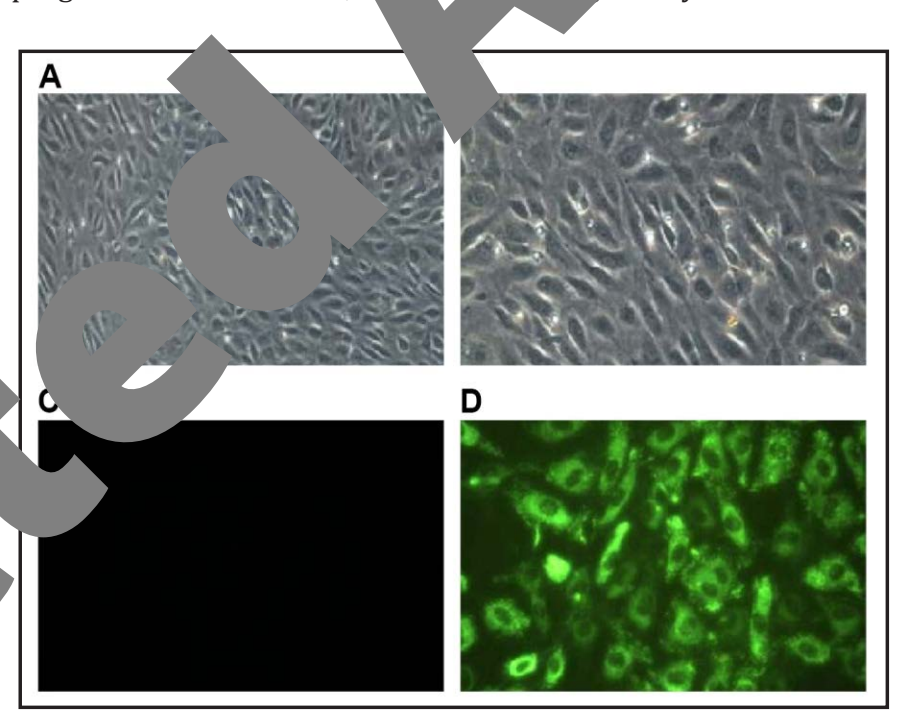

Fig. 2. The morphology and identification of HUVECs as observed under an inverted microscope. A, primary cultured HUVECs under an inverted microscope $(100 \times)$; B, primary cultured HUVEC under an inverted microscope $(200 \times)$; , endothelial cells of the control group of the VIII factor-related antigen labeling experiment; and D, endothelial cells with positive VIII factor-related antigen expression ( $\times 200)$; HUVECs, human umbilical vein endothelial cells.

was significantly decreased while that in the miR-499 inhibitor group was significantly increased $(P<0.05)$. A change in luciferase relative activity was not observed following the co-transfection of the NC, miR-499 mimic and miR-499 inhibitor with mutant PDCD4 3'UTRMUT $(P>0.05)$ (Fig. 3B). The results were consistent with the bioinformatics prediction and further confirmed that miR-499 could bind with the 3'-UTR of PDCD4 mRNA, suggesting the targeted inhibition of PDCD4 by miR-499. 
Fig. 3. Analysis of the relative luciferase activity from the PDCD4 3'UTR and miR-499. A: prediction of the relationship between $\mathrm{miR}-499$ and PDCD4 3'UTR; and B: luciferase activity analysis; ${ }^{*}, \mathrm{P}<0.05$, compared with the NC group; NC, negative control; miR-499, microRNA-499; and PDCD4, programmed cell death 4; Each experiment was repeated three times.

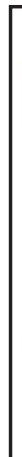

Fig. 4. Comparison of the mRNA expressions of miR-499 and PDCD4 in each group as detected by qRTPCR. A, miR-499 mRNA expression in plasma as detected by qRT-PCR; $B$ PDCD4 mRNA expression in plasma as detected by qRT-PCR; $\mathrm{P}<0.05$, statistically significar ${ }^{*}$ differences $\quad(\mathrm{P}<0.05) \quad \mathrm{w}$ presented using different lette qRT-PCR, quantitative rez he polymerase chain reactio hiR499, microRNA-499; and programmed cell experiment was times.
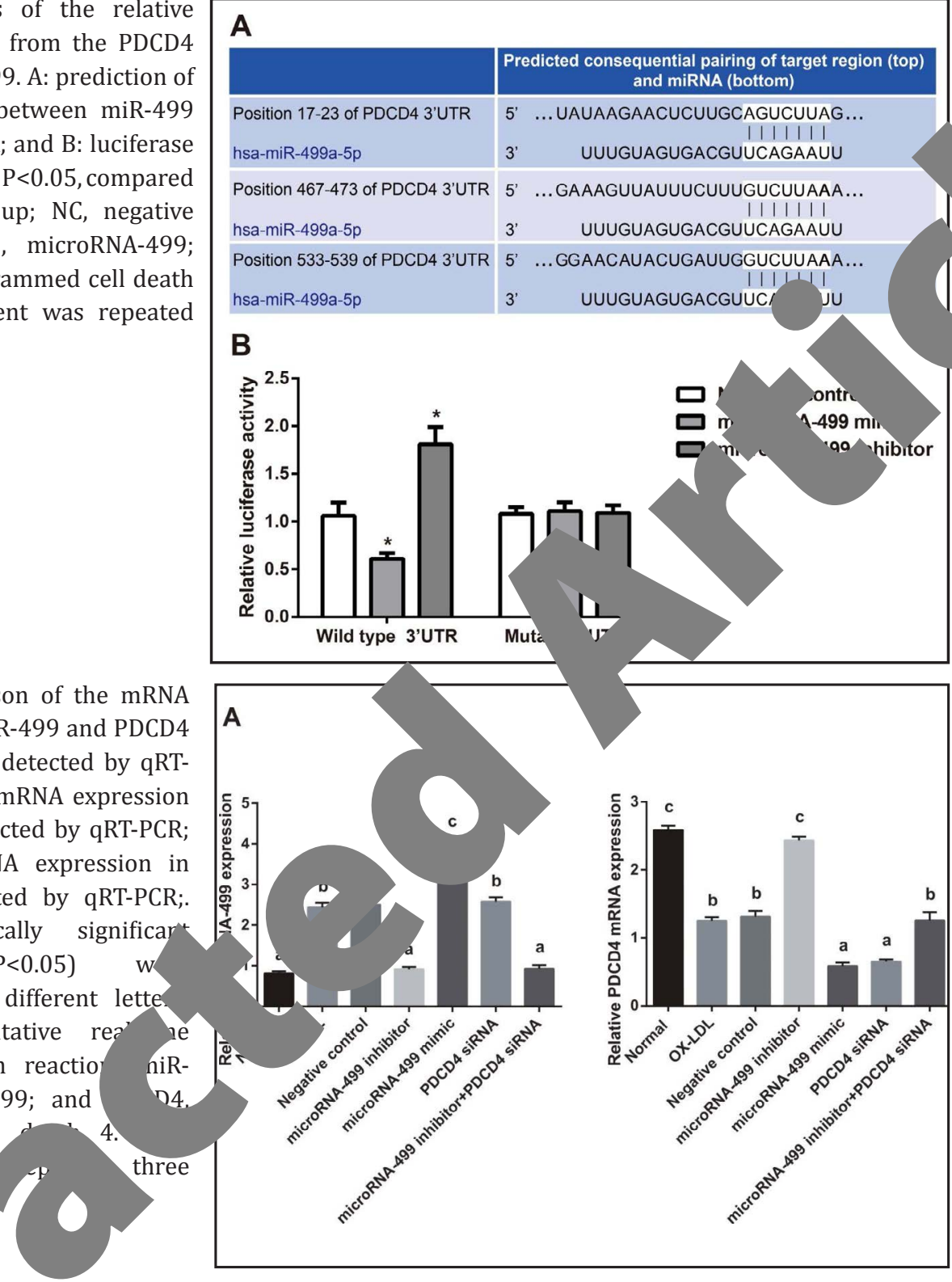

\section{B}
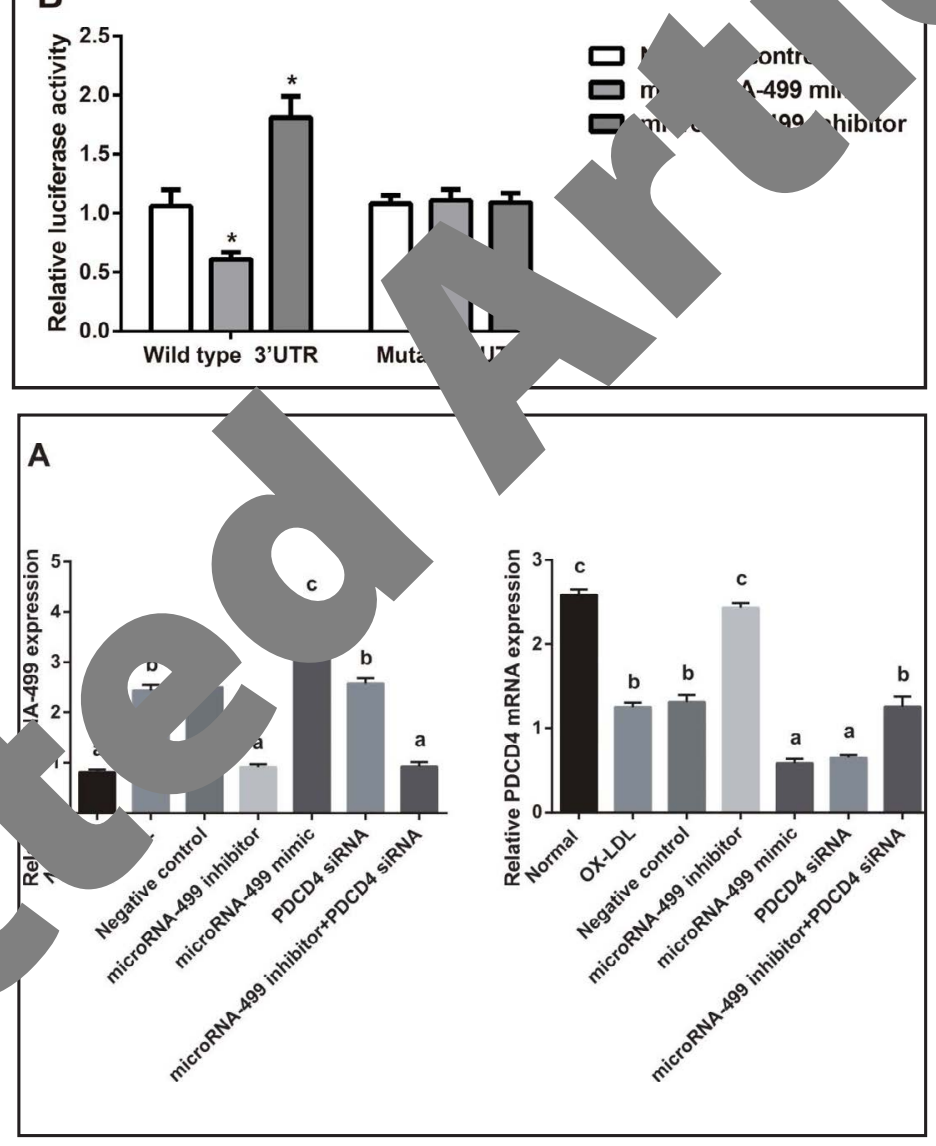

ons of the mRNA expressionsof miR-499 and PDCD4 in each group

ompa ith the normal group, miR-499 expression was up-regulated in the OX-LDL, W, 4.9 nimic and PDCD4 siRNA groups $(P<0.05)$. MiR-499 expression was significantly -re $d$ in the miR-499 mimic group (Fig. 4A). Compared with the normal group, CD4 expressions in the OX-LDL, NC, miR-499 mimic, PDCD4 siRNA and miR-499 inhibitor F 5 D4 siRNA groups were significantly decreased $(P<0.05)$. There was no significant crence between the miR-499 inhibitor and normal groups $(P>0.05)$. Compared with the OX-LDL and NC groups, PDCD4 expression in the miR-499 inhibitor group was increased while those in the miR-499 mimic and PDCD4 siRNA groups were decreased $(P<0.05)$. No significant differences were found in the miR-499 inhibitor + PDCD4 siRNA group $(P>0.05)$ (Fig. 4B).

Effect of miR-499 targeting PDCD4 on cell proliferation in each group

The MTT assay was performed to measure the cell proliferation rate in each group. The results showed that compared with the normal group, the cell survival rate was significantly 
Fig. 5. Effect of miR-499 targeting PDCD4 on cell viability in each group as detected by the MTT assay. miR-499, microRNA-499; PDCD4, programmed cell death 4; and MTT, methyl-thiazolyl-tetrazolium. Each experiment was repeated three times. Statistically significant differences $(\mathrm{P}<0.05)$ were presented using different letters.

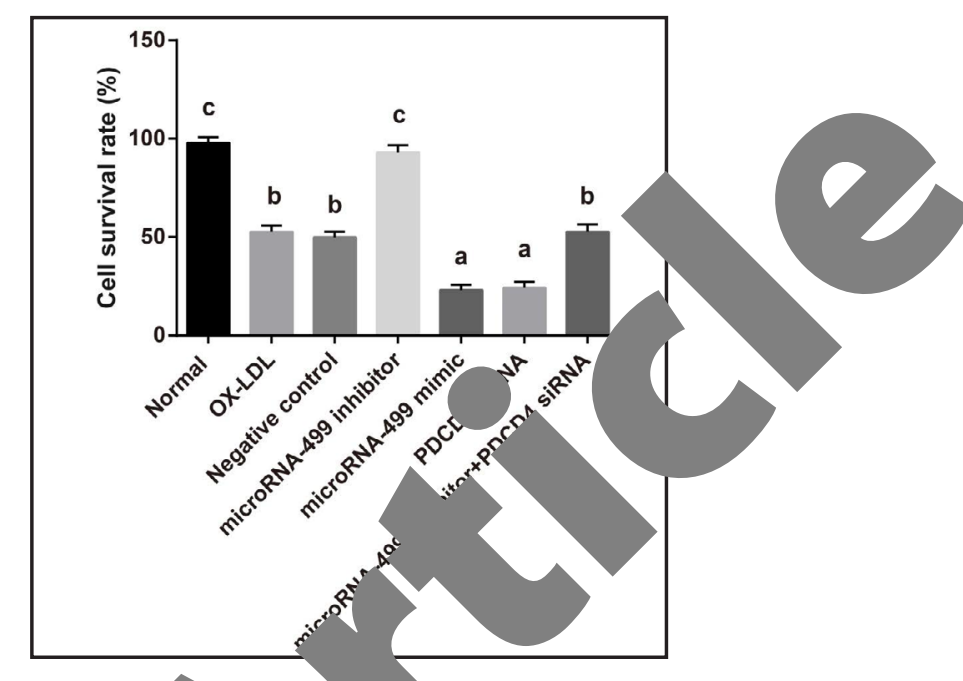

Table 2. Comparisons of expressions of inflammatory cytokines in group (pg/mL), Note: miR-499, microRNA-499; PDCD4, programmed cell death 4, IL-1, Interleukin-1; TNF- $\alpha$, Tumor necrosis factor alpha; NC, nega co erent letters showed significant difference, miR-499, microRNA-499; PDCD4 programmed eath 4; qRT-PCR, quantitative real-time polymerase chain reaction; $\mathrm{P}<0.05$, each $\mathrm{e}$ for the times, NC, negative control

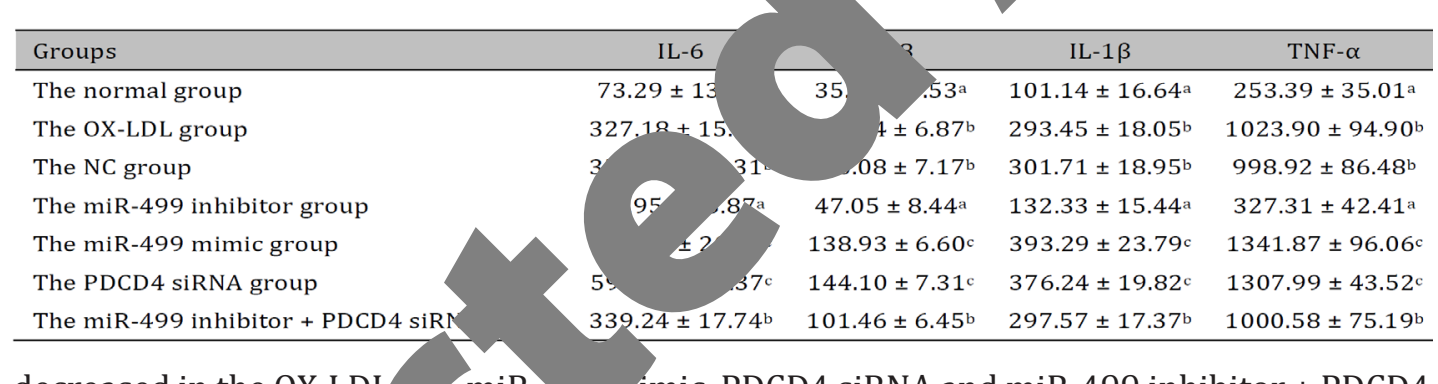

decreased in the OX-LDI siRNA groups $(P<0.05)$ in the miR-499 inhibitor 6, miR-4 Aimic, PDCD4 siRNA and miR-499 inhibitor + PDCD4 $>0.05$ ). Compared with the OX-LDL and NC groups, the cell survival rat mintrantly increased in the miR-499 inhibitor group while those in the miR-499 n ni CD4 siRNA groups were significantly decreased $(P<0.05)$. There was no sic fical lif nce in the miR-499 inhibitor + PDCD4 siRNA group $(P>0.05)$. Compar ith $\mathrm{t} \quad \mathrm{CD} 4$ siRNA group, the cell survival rate was significantly increased i' the m inhibitor + PDCD4 siRNA group $(P<0.05)$. No significant differences were setv he miR-499 mimic and PDCD4 siRNA groups $(P>0.05)$ (Fig. 5). R-499 inhibitor + PDCD4 siRNA groups $(P<0.05)$. Compared with the normal group, there was no significant difference in the miR-499 inhibitor group $(P>0.05)$. Compared with the OX-LDL and NC groups, the levels of IL-6, IL-8, IL-1 $\beta$ and TNF- $\alpha$ were significantly decreased in the miR-499 inhibitor group while those in the miR-499 mimic and PDCD4 siRNA groups were significantly increased $(P<0.05)$. There was no significant difference in the miR-499 inhibitor + PDCD4 siRNA group $(P>0.05)$. Compared with the PDCD4 siRNA group, the levels of IL-6, IL-8, IL-1 $\beta$ and TNF- $\alpha$ were significantly decreased in the miR-499 inhibitor + PDCD4 siRNA group $(P<0.05)$. There was no significant difference between the miR-499 mimic and PDCD4 siRNA groups $(P>0.05)$ (Table 2).

\section{KARGER}



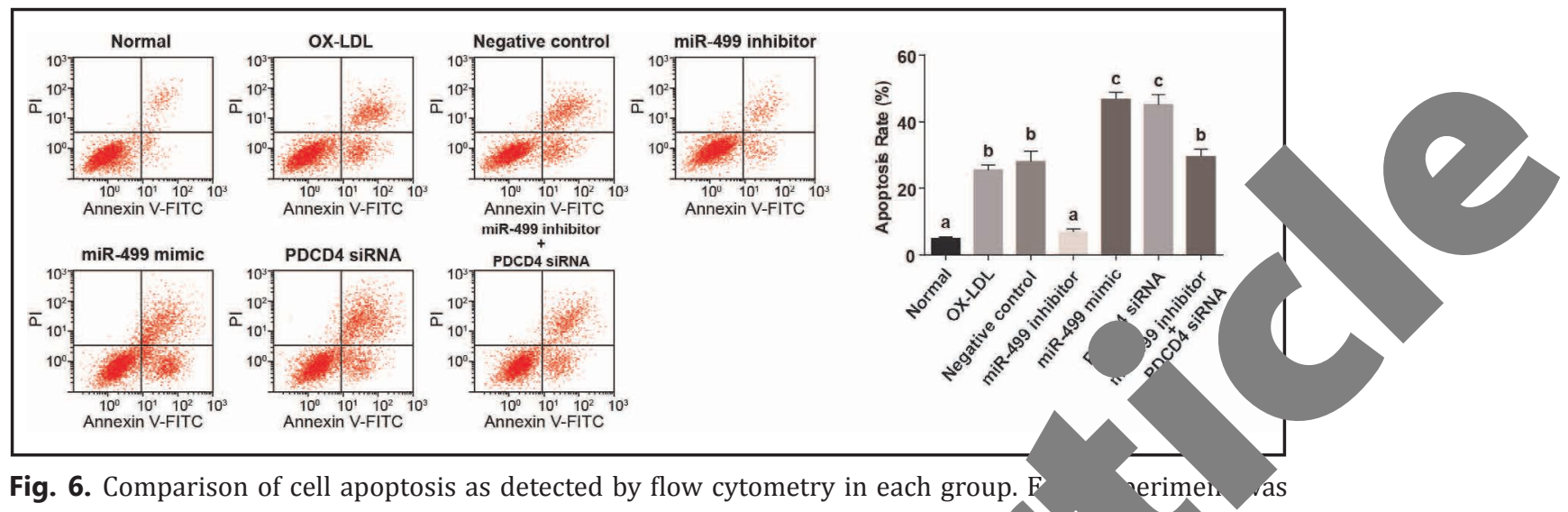

Fig. 6. Comparison of cell apoptosis as detected by flow cytometry in each group. F repeated three times. Statistically significant differences $(\mathrm{P}<0.05)$ were presented $\mathrm{u}$ dì

Table 3. Comparisons of mRNA expressions of NF- $\kappa B / T N F-\alpha$ signaling pathway d proteins detected by qRT-PCR in each group Note: miR-499, microRNA-499; PDCD rammea leath 4; ICAM-1, intercellular cell adhesion molecule-1; MCP-1, monocyte chemo ic 1 ; Vo. adhesion molecule-1; NF-кB, nuclear factor-kappa B; TNF- $\alpha$, tumor os pha; different letters showed significant difference, $\mathrm{P}<0.05$; qRT-PCR, quantitative real-th symerase chain reaction; each experiment was repeated for three times, NC, negativ rol

\begin{tabular}{|c|c|c|c|c|}
\hline Groups & NF-кB & VC. $M-1$ & ICAM-1 & MCP-1 \\
\hline The normal group & 0 . & $0.73 \pm 0.06^{a}$ & $0.84 \pm 0.07 \mathrm{a}$ & $0.44 \pm 0.02$ \\
\hline The OX-LDL group & 3.08 & $2.24 \pm 0.10^{\mathrm{b}}$ & $3.52 \pm 0.13^{b}$ & $1.74 \pm 0.06$ \\
\hline The NC group & & $2.29 \pm 0.14^{b}$ & $3.58 \pm 0.11^{\mathrm{b}}$ & $1.80 \pm 0.04$ \\
\hline The miR-499 inhibitor group & & $0.80 \pm 0.04^{a}$ & $0.89 \pm 0.08 \mathrm{a}$ & $0.48 \pm 0.03$ \\
\hline The miR-499 mimic group & & $4.34 \pm 0.17^{\mathrm{c}}$ & $5.81 \pm 0.18^{\mathrm{c}}$ & $3.32 \pm 0.15$ \\
\hline The PDCD4 siRNA group & & $4.37 \pm 0.19 c$ & $5.93 \pm 0.22^{c}$ & $3.36 \pm 0.03$ \\
\hline The miR-499 inhibitor + PDCD4 siRh & & $2.23 \pm 0.12^{b}$ & $3.61 \pm 0.15^{b}$ & $1.73 \pm 0.04$ \\
\hline
\end{tabular}

Effect of miR-499 to ta

Flow cytome detect cell apoptosis. The results showed that compared with the norm of the cell apoptosis rate was significantly increased in the OX-LDL, NC, miR-499 an a 4 siRNA and miR-499 inhibitor + PDCD4 siRNA groups $(P<$ 0.05). Con red re normal group, there was no significant difference in the miR-499 inhibit up ( .05). Compared with the OX-LDL and NC groups, the cell apoptosis ficantly decreased in the miR-499 inhibitor group while those in the miR-499 and 4 siRNA groups were significantly increased (both $P<0.05$ ). There was no S. 0.4 ditierence in the miR-499 inhibitor + PDCD4 siRNA group $(P>0.05)$. Compared ith $C D 4$ siRNA group, the cell apoptosis rate was significantly decreased in the miRinhibitor + PDCD4 siRNA group $(P<0.05)$. There was no significant difference between he iR-499 mimic and PDCD4 siRNA groups $(P>0.05)$ (Fig. 6).

Effect of miR-499 targeting PDCD4 on the NF- $\mathrm{B} / \mathrm{TNF}-\alpha$ signaling pathway-related proteins in each group

The qRT-PCR and western blotting were used to determine the mRNA and protein expressions of NF- $\kappa B / T N F-\alpha$ signaling pathway-related proteins (NF- $\kappa B$, TNF- $\alpha$, VCAM1, ICAM-1 and MCP-1) in each group. The results showed that compared with the normal group, the mRNA and protein expressions of NF- $\kappa B$, TNF- $\alpha$, VCAM-1, ICAM- 1 and MCP-1 were significantly increased in the OX-LDL, NC, miR-499 mimic, PDCD4 siRNA and miR-499 inhibitor + PDCD 4 siRNA groups $(P<0.05)$. Compared with the normal group, there was no significant difference in the miR-499 inhibitor group $(P>0.05)$. Compared with the OX-LDL

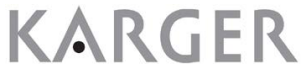




\section{\begin{tabular}{lll} 
Cellular Physiology & \multicolumn{1}{c}{ Cell Physiol Biochem 2017;44:110-124 } \\
DOI: 10.1159/000484588 & 2017 The Author(s). Published by S. Karger AG, Basel
\end{tabular}

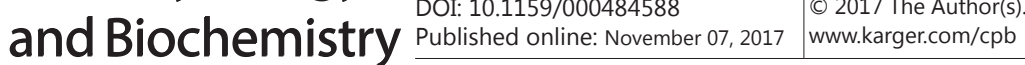

Zhang et al.: Effects of Mir-499 On CAD by Targeting PDCD4

Fig. 7. Comparison of the expressions of NF- $\mathrm{B} / \mathrm{TNF}-\alpha$ signaling pathway-related proteins as detected by Western blotting in each group. A: Western blotting bands of NF- $\kappa B$, TNF- $\alpha$, VCAM- 1 and ICAM-1 proteins; and B, C, D, E and F: histograms for the NF- $\mathrm{BB}$, TNF- $\alpha$, VCAM-1, ICAM-1 and MCP-1 proteins; NF-kB, nuclear factor-kappa B; TNF- $\alpha$, tumor necrosis factor-alpha; VCAM-1, vascular cell adhesion molecule-1; ICAM1, intercellular adhesion molecule-1; and MCP-1, monocyte chemotactic protein-1. Each experiment w repeated three times. Statistically significant differences $(\mathrm{P}<0.05)$ were presented using different letters.
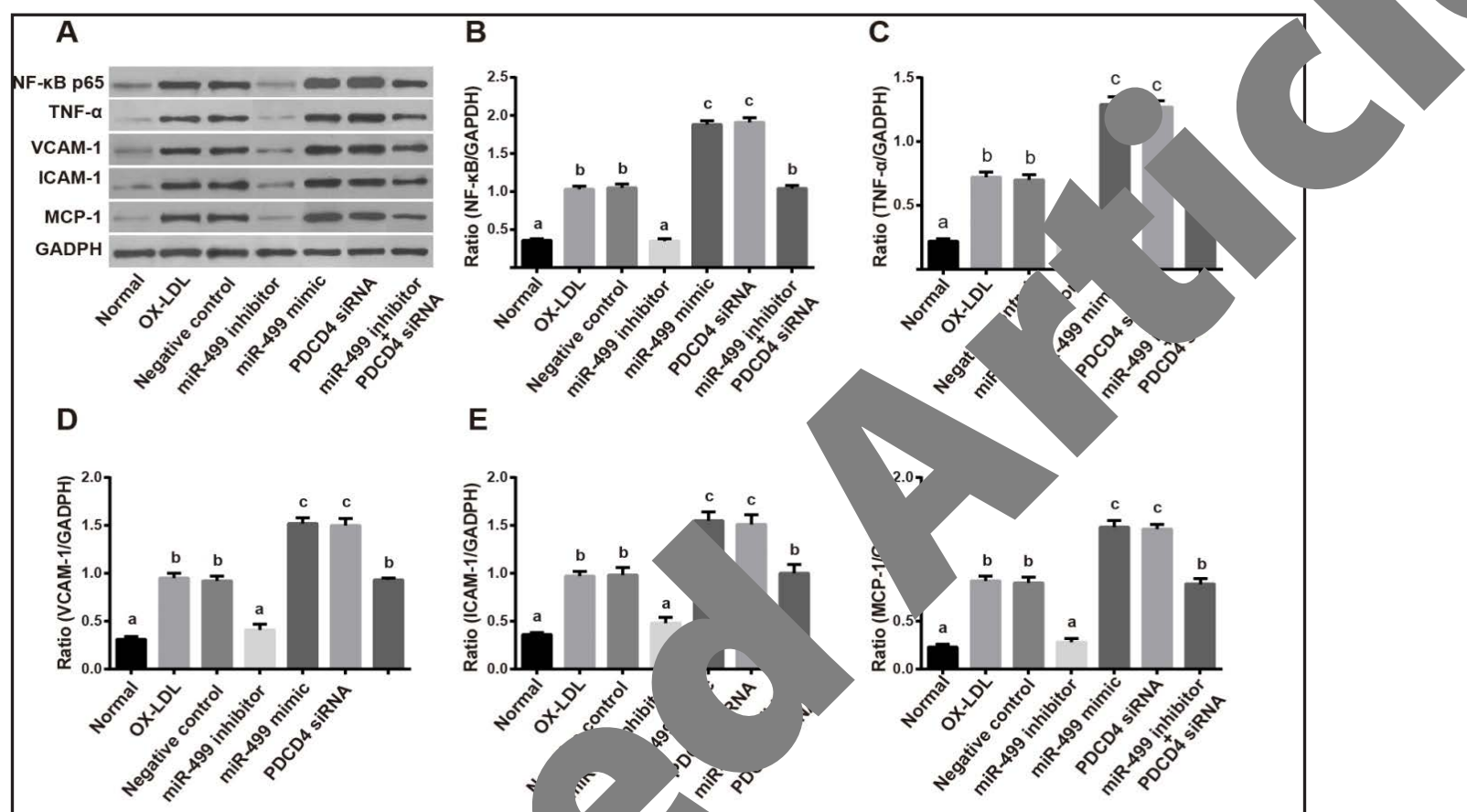

E
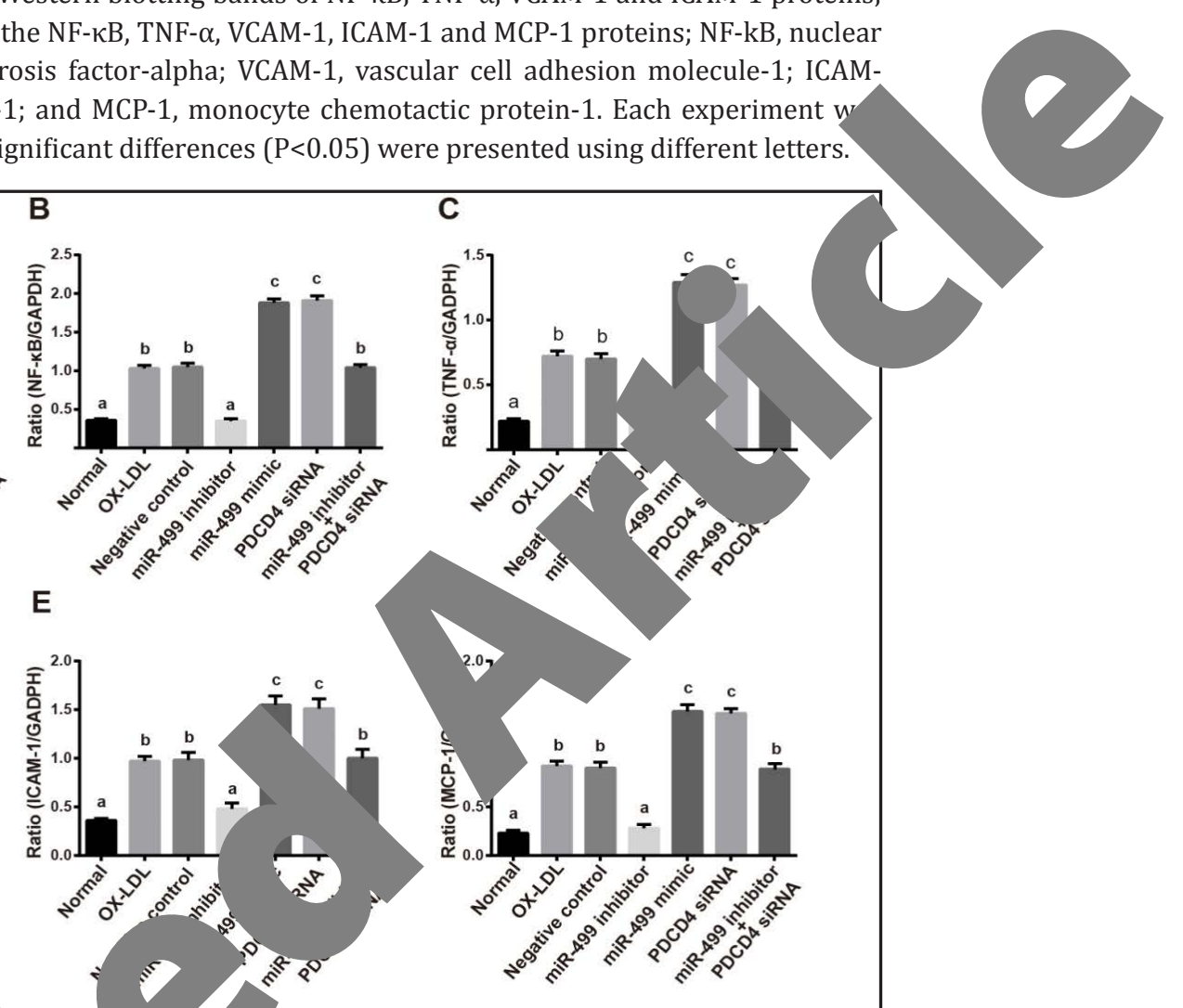

and NC groups, the mRNA MCP-1 was significantly

ein expression of NF- $\kappa B$, TNF- $\alpha$, VCAM-1, ICAM-1 and 499 mimic and PDCD4 AA groups were significantly increased $(P<0.05)$. There was no significant difference in ${ }^{\circ} \quad 9$ inhibitor + PDCD4 siRNA group $(P>0.05)$. Compared with the PDCD4 gro 4 mRA and protein expressions of NF- $\kappa B$, TNF- $\alpha$, VCAM-1, ICAM-1 and $M$ significantly decreased in the miR-499 inhibitor + PDCD4 siRNA group $(P<005) . T$ re no significant difference between the miR-499 mimic and PDCD4 siRNA gro ( $(P \quad$ (Table 3, Fig. 7).

is are the essential components of various inflammatory diseases, such as psoriasis, di tes, cancer and rheumatoid arthritis, and chronic inflammation is related to increased erosclerosis and accelerated cardiovascular mortality and morbidity [23]. Endothelial dysfunction is regarded as one of the significant reason for cardiovascular disease [24]. Increasing evidence has elucidated that mRNAs play a key role in regulating myocardial apoptosis [25, 26]. In our study, we verified the roles of miR-499 and PDCD4 in endothelial cells during CAD.

Our results provided evidence that miR-499 expression was elevated and PDCD4 was down-regulated in the plasma ofCAD patients compared to that in the normal group, indicating that miR-499 was negatively correlated with PDCD4. A change in miR-499 expression might be involved in the modulation of the expression of multiple genes and signaling transduction

\section{KARGER}




\section{Cellular Physiology

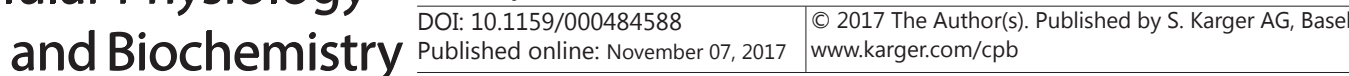

Zhang et al.: Effects of Mir-499 On CAD by Targeting PDCD4

pathways. Recent studies have identified several target genes of miR-499, such as Drp1 and Ets1 $[27,28]$. The tumor suppressor PDCD 4 is often down-regulated in several malignancies, and its protein expression could be modulated by miR-21, indicating that PDCD4 downregulation is a reliable biomarker for early-stage squamous cell esophageal neoplasia [29] In addition, compared to the normal group, NF- $\mathrm{KB}$ and TNF- $\alpha$ expression and the apopto rates were all increased. The NF- $\kappa \mathrm{B} / \mathrm{TNF}-\alpha$ signaling pathway has been reported to promot cancer cell growth, angiogenesis, invasion, and eventually metastasis in many human tumors $[30,31]$. As an important transcription factor, NF- $\kappa B$ is responsible for a variety of biolog processes that participate in the transcription of proinflammatory genes, ther medi cellular inflammatory responses, including the elevated expression of che kines cytokines [32]. Activation of constitutive NF-kB has been reported to modulat rfero biological functions, such as cell proliferation, angiogenesis, and inhibitio f ' F-K ich protect against atherosclerosis [33]. Silencing of miR-499 could lead to $\mathrm{n}$ and invasion of colorectal cancer (CRC) cells in vitro by modulating $\mathrm{P}^{\mathrm{r}}$ concluded that down-regulated miR-499 expression inhibited apoptocis inflammatory factors as well as improved CAD by modulating its fur. by inhibiting the NF- $\kappa \mathrm{B} / \mathrm{TNF}-\alpha$ signaling pathways.

In addition, we also found that the levels of IL-6, ILmiR-499 inhibitor and miR-499 inhibitor + PDCD4 siRNA gi siRNA group. The endothelial cells can express 59 inflammato cytokines, chemokine and cytokine receptors inflamma thus, inflammatory cytokines will be conseque creted by inflammatory activation of endothelial cells [34]. As small and active pr cytokines regulate cellular growth, function, and differentiation as well as cont the une response and inflammation, including some proinflammatory cytokines su s IL d IL-8 [35].

Additionally, the results showed the of TNF- $\alpha$, NF- $\kappa B$, VCAM-1, ICAM-1 and MCP-1 were reduced in the miR 9 Ditor and miR-499 inhibitor + PDCD4 siRNA groups while enhanced in the PDCI master switch and also ind tra the production of some inf tory lactors [36]. In the vascular endothelium, NF- $\mathrm{BB}$ activation induces the ey ess roinflammatory genes, including those encoding adhesion molecules, cyt ies, ana moattractant proteins, which collectively contribute to the initiation and dev men of atherosclerosis [37]. As a proinflammatory, pleiotropic, and homotrimeric colub. $\quad$, TNF- $\alpha$ is involved in various metabolic disorders, such as diabetes mel anurneumatoid arthritis [39], and disorders with an inflammatory background, i af of not limited to, atherosclerosis [40]. TNF- $\alpha$ results in the initiation of transcri ona so wes via the rapid activation of NF- $\mathrm{KB}$ [41]. Chronic inflammation is also a c al fea atherosclerotic vascular disease, in which TNF- $\alpha$ causes endothelial $d$ 'sfunc hat leads to reduced vasodilatory responses [42]. It has been shown that nibit. inflammatory pathways may be beneficial for the prevention of vascular $\mathrm{TNF}$, has also been shown to stimulate endothelial microparticles (EMPs) that are ndothelial cells and participate in the apoptosis of endothelial cells. Therefore,
n- $\alpha$ immbitor have an emerging role in the prevention of vascular dysfunction [43]. A study

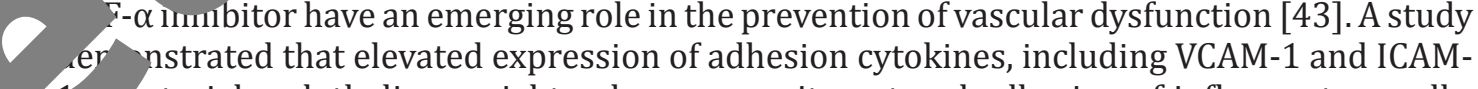
arterial endothelium, might enhance recruitment and adhesion of inflammatory cells, ontributing to the progression of plaque instability and atherosclerosis [44]. Elevated levels of ICAM-1 have been found in patients with coronary heart disease, and circulating VCAM1 levels could be employed to determine the stage of atherosclerosis; additionally, a role for MCP-1 in atherogenesis has also been recently proven [45]. The expressions of VCAM-1, ICAM-1 as well as MCP-1 can be mediated by NF- $\mathrm{kB}$ [46]. Thus we can reach a conclusion that down-regulated miR-499 expression protected endothelial cells from inflammatory damage during CAD through the NF- $\mathrm{KB} / \mathrm{TNF}-\alpha$ signaling pathway. 


\section{Cellular Physiology \begin{tabular}{ll|l} 
and Biochemistry & $\begin{array}{l}\text { DOI: 10.1159/000484588 } \\
\text { Published online: November 07, } 2017\end{array}$ & $\begin{array}{l}\text { (C) } 2017 \text { The Author(s). Published by S. Karger AG, Basel } \\
\text { www.karger.com/cpb }\end{array}$ \\
\hline
\end{tabular}}

Zhang et al.: Effects of Mir-499 On CAD by Targeting PDCD4

\section{Conclusion}

Our findings have illustrated that low miR-499 expression contributes to high PDCD4 expression and protects the endothelial cells against inflammatory damage through the NF$\kappa B / T N F-\alpha$ signaling pathway during CAD. Therefore, miR-499 could be a potential target $f$ the treatment of CAD.

\section{Acknowledgements}

We would like to give our sincere appreciation to the reviewers for th comments on this article.

\section{Disclosure Statement}

The authors declare that they have no competing inter

\section{References}

1 Jung JH, Song GG, Kim JH, Seo YH, Choi SJ: Association tor XIII Val3 artery disease: A meta-analysis. Cardiol J 2016;10.56 16.0070

2 Mahmoodi K, Nasehi L, Karami E, Soltanpour MS:

Nitric Oxide Synthase G894T Polymorphism with $C$

Specialist Int 2016;32:105-112.

-3 Yayla C, Okyay K, Yilmaz A, Sahinarslan A

A: Association of rs10757274 and rs238

in Turkish Population. Korear

4 Ning FL, Wang F, Li ML, Yu ZS.

small cell lung cancer to ci- tirn $\mathrm{h}$

916

AS, cyiol A, Bolayir HA, Sezenoz B, Menevse S, Cengel

ratic itric Oxide Levels and Endothelial

polymorphism and coronary

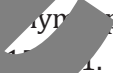

Chen So.microRNA-182 modulates chemosensitivity of human non-

g PDCD4. Diagn Pathol 2014;9:143.

5 Xin Y, Yang C, Han Z: Cir ang miR-4 a potential biomarker for acute myocardial infarction. Ann Transl Med 2016;4:135

Zhao $\mathrm{CH}$, Cheng CC He $\mathrm{K}$ microRNA-49 2015;14:40 49 Biochem 2013;114:1464-1473.

Wei N, Liu SS, Chan KK, Ngan HY: Tumour suppressive function and modulation of programmed cell death 4 (PDCD4) in ovarian cancer. PLoS One 2012;7:e30311.

-12 Cao W, Hu C, Wu L, Xu L, Jiang W: Rosmarinic acid inhibits inflammation and angiogenesis of hepatocellular carcinoma by suppression of NF-kappaB signaling in H22 tumor-bearing mice. J Pharmacol Sci 2016;132:131-137.

13 Li L, Hu M, Zheng L, Zhang C, Li J, Rong R, Zhu T, Jia Y: Endothelin Receptor Down-Regulation Mediated Ligand Regulation Mechanisms Protect Against Cellular Hypoxia Injury in Rat Vascular Endothelial Cells. 


\section{Cellular Physiology \begin{tabular}{l|l|l} 
and Biochemistry 10.1159/000484588 & $\begin{array}{l}\text { (c) } 2017 \text { The Author(s). Published by S. Karger AG, Basel } \\
\text { www.karger.com/cpb }\end{array}$
\end{tabular}

Cell Physiol Biochem 2016;40:1443-1454.

14 Xiang N, He M, Ishaq M, Gao Y, Song F, Guo L, Ma L, Sun G, Liu D, Guo D, Chen Y: The DEAD-Box RNA Helicase DDX3 Interacts with NF-kappaB Subunit p65 and Suppresses p65-Mediated Transcription. PLoS One 2016;11:e0164471.

15 Song L, Kang C, Sun Y, Huang W, Liu W, Qian Z: Crocetin Inhibits Lipopolysaccharide-Induced Inflammator Response in Human Umbilical Vein Endothelial Cells. Cell Physiol Biochem 2016;40:443-452.

-16 Gane JM, Stockley RA, Sapey E: TNF-alpha Autocrine Feedback Loops in Human Monocytes: The Pro- and Anti-Inflammatory Roles of the TNF-alpha Receptors Support the Concept of Selective TNFR1 Blockade Vivo. J Immunol Res 2016;2016:1079851.

17 Cho HC, Yu G, Lee MY, Kim HS, Shin DH, Kim YN: TNF-alpha polymorphisms and coronary c association study in the Korean population. Cytokine 2013;62:104-109.

-18 O'Rourke RA, Brundage BH, Froelicher VF, Greenland P, Grundy SM, Hachamovitch R, LJ, Weintraub WS, Winters WL, Jr: American College of Cardiology/American Heart A Consensus Document on electron-beam computed tomography for the diagnosis an 1 artery disease. J Am Coll Cardiol 2000;36:326-340.

19 Kadi H, Ceyhan K, Sogut E, Koc F, Celik A, Onalan O, Sahin S: Mildly decreased g. associated with poor coronary collateral circulation in patients wit 2011;34:617-621.

-20 Jiang YR, Miao Y, Yang L, Xue M, Guo CY, Ma XJ, Yin HJ, Shi DZ, Chen containing serum for activating-blood and dispelling-toxin on ox-LD expression in endothelial cells. Chin J Integr Med $20 \quad$ 8:30-33.

-21 Chen X, Zhang L, Su T, Li H, Huang Q, Wu D, Yang C, h. rinetics of pl acute myocardial infarction. J Thorac Dis 2015;7:890- 9 .

-22 Hanifehpour R, Motevalli M, Ghanaati H, Shahriari Calcium Score Less than 100 in Excluding Coronar Gerhardt S, Konig V, Doll M, Hailemariam-Ja M: Dimethylfumarate protects against Ty endothelial cells. J Inflamm (Lond) 2015

-24 Han F, Hui Z, Zhang S, Hou N, endothelial dysfunction in rat

$$
\text { 1ya) abeh M: Diagnostic Accuracy of Coronary }
$$
ry D _. Iran J Radiol 2016;13:e16705. er N, Kaufmann R, Kippenberger S, Meissner

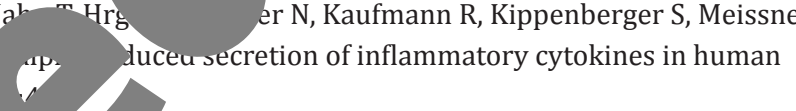
of haemeoxygenase- 1 improves FFA-induced ell Phys...solochem 2015;35:1230-1240.

-25 Skommer J, Rana I, Marque Z, Ln, Charchar FJ: Small molecules, big effects: the role of microRNAs in regulation ardiomy death. Cell Death Dis 2014;5:e1325.

-26 Lai KB, Sanderson JE, Iz L IB, Yu M Micro-RNA and mRNA myocardial tissue expression in biopsy specimen from patients Alure. Int J Cardiol 2015;199:79-83.

-27 Wang JX, Jiao ng b, wang K, Liu JP, Li YR, Li PF: miR-499 regulates mitochondrial dynamics by targeting ce le vnamin-related protein-1. Nat Med 2011;17:71-78.

28 Wei W, Z, Fu Cie Mang H, Wu Y, Zheng X: MicroRNA-1 and microRNA-499 downregulate the exp rof th roto-oncogene in HepG2 cells. Oncol Rep 2012;28:701-706.

20 Fass Realdon S, Pizzi M, Balistreri M, Battaglia G, Zaninotto G, Ancona E, Rugge M: Programmed 1 dea clear loss and miR-21 or activated Akt overexpression in esophageal squamous cell cinogen, is. Dis Esophagus 2012;25:263-268. a SY, Wu B: TRIM29 Overexpression Promotes Proliferation and Survival of Bladder Cancer Cells

A througn NF-kappaB Signaling. Cancer Res Treat 2016;48:1302-1312. Dysfunction through Inhibiting ROS and TNF-alpha Generation, by Maintaining Mitochondrial Dynamic Network and by Increasing IL-6 Level during Chronic Fatigue. Front Pharmacol 2016;7:328.

Xie Y, Li Y, Cai X, Wang X, Li J: Interleukin-37 suppresses ICAM-1 expression in parallel with NFkappaB down-regulation following TLR2 activation of human coronary artery endothelial cells. Int Immunopharmacol 2016;38:26-30.

33 Qin W, Xie W, Xia N, He Q Sun T: Silencing of Transient Receptor Potential Channel 4 Alleviates oxLDLinduced Angiogenesis in Human Coronary Artery Endothelial Cells by Inhibition of VEGF and NF-kappaB. Med Sci Monit 2016;22:930-936.

-34 Krogmann A, Staiger K, Haas C, Gommer N, Peter A, Heni M, Machicao F, Haring HU, Staiger H: Inflammatory response of human coronary artery endothelial cells to saturated long-chain fatty acids. Microvasc Res 


\section{Cellular Physiology Cell Physiol Biochem 2017;44:110-124

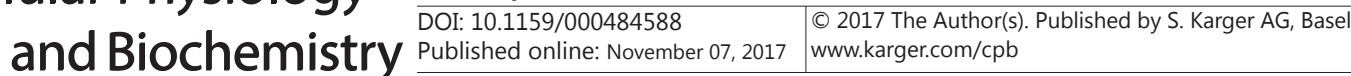 \\ Zhang et al.: Effects of Mir-499 On CAD by Targeting PDCD4}

2011;81:52-59.

-35 Arican 0, Aral M, Sasmaz S, Ciragil P: Serum levels of TNF-alpha, IFN-gamma, IL-6, IL-8, IL-12, IL-17, and IL-18 in patients with active psoriasis and correlation with disease severity. Mediators Inflamm 2005;2005:273-279.

-36 Han F, Guo Y, Xu L, Hou N, Han F, Sun X: Induction of Haemeoxygenase-1 Directly Improves Endothelial Function in Isolated Aortas from Obese Rats through the Ampk-Pi3k/Akt-Enos Pathway. Cell Physiol Biochem 2015;36:1480-1490.

-37 Zhong Y, Cheng CF, Luo YZ, Tian CW, Yang H, Liu BR, Chen MS, Chen YF, Liu SM: C-reactive protein stimulates RAGE expression in human coronary artery endothelial cells in vitro via ROS genoration an ERK/NF-kappaB activation. Acta Pharmacol Sin 2015;36:440-447.

38 Nystrom T, Nygren A, Sjoholm A: Increased levels of tumour necrosis factor-alpha (TNF-alpha? with Type II diabetes mellitus after myocardial infarction are related to endothelial dy on (Lond) 2006;110:673-681.

39 Ohta S, Harigai M, Tanaka M, Kawaguchi Y, Sugiura T, Takagi K, Fukasawa C, Hara M. necrosis factor-alpha (TNF-alpha) converting enzyme contributes to production of tissues from patients with rheumatoid arthritis. J Rheumatol 2001;28:1756-1>

40 Bruunsgaard H, Skinhoj P, Pedersen AN, Schroll M, Pedersen BK: Ar tumour n (TNF-alpha) and atherosclerosis. Clin Exp Immunol 2000;121:2

-41 Szukiewicz D, Wojciechowska M, Bilska A, Stangret A, Szewczyk G, Aspirin Action in Endothelial Cells: Different Patterns of Response B and TNF-alpha/TNFR1 Signaling Pathways. Cardioy Orugs Ther 20 :219-229.

-42 Yang WS, Moon SY, Lee MJ, Park SK: Epigallocatechin Gte Attenuat effects of TNF-alpha in Vascular Endothelial Cells by Causing Ectodomain Sher TNF Receptor 1. Cell Physiol Biochem 2016;38:1963-1974.

43 Barbaro NR, de Araujo TM, Tanus-Santos JE, Anhe Hypertension: TNF-Alpha Inhibition Effects ando

\section{ntan} Yang JX, Pan YY, Ge JH, Chen B, Mao W, Qj Expression of VCAM-1 and ICAM-1 in Er Cell Physiol Biochem 2016;40

-45 Papayianni A, Alexopoulos E, 6 levels of ICAM-1, VCAM-1, inflammation, dyslipidar

-46 Liang B, Wang X, Zhang Angiotensin II-Induced $\mathrm{I}$

\section{,}

\section{l

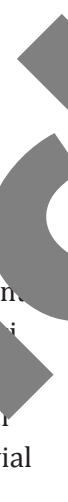
Suppression NF-nuppaB Pathways in HUVECs. Cell Physiol Biochem 2015;35:2472-2482. cvents. Nephrol Dial Transplant 2002;17:435-441.

ng H, ' ri R, Liu M, Bian Y, Xiao C, Yang Z: Angiotensin-(1-7) Attenuates $M-1$, and MCP-1 Expression via the MAS Receptor Through

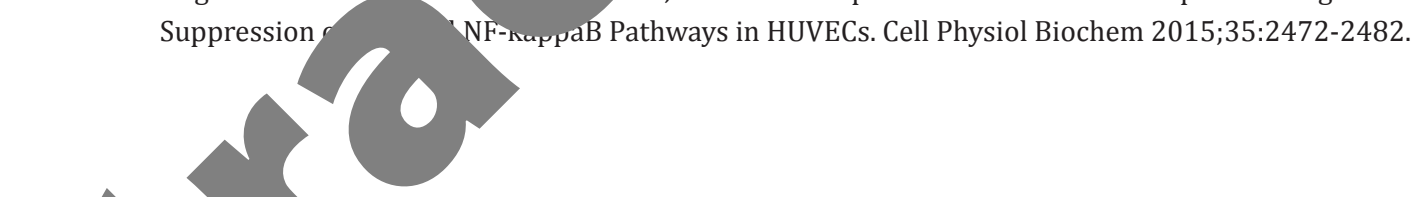

